\title{
The Association Between Femoroacetabular Impingement and Internal Fixation of Femoral Neck Fractures
}

\author{
Femoroasetabular Sıkışma ve Femur Boyun Kırıklarının İ̧ten Tespiti Arasındaki Illişki
}

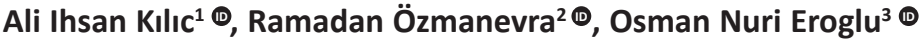 \\ ${ }^{1}$ Department of Orthopedics and Traumatology, Siirt State Hospital, Siirt, Turkey \\ ${ }^{2}$ Department of Orthopedics and Traumatology, University of Kyrenia, Kyrenia, Northern Cyprus \\ ${ }^{3}$ Department of Orthopedics and Traumatology, Dokuz Eylül University, İzmir, Turkey
}

Geliş / Received: 05.05.2021 Kabul / Accepted: 08.06.2021 Online Yayın / Published Online: 10.08.2021

Cite as: Kılıc Al, Özmanevra R, Eroglu ON. The association between femoroacetabular impingement and internal fixation of femoral neck fractures. Turk J Hip Surg 2021;1(2):45-50.

\section{ABSTRACT}

Objective: Congenital deformities, slipped capital femoral epiphysis and Legg-Calve-Perthes disease have been suggested as possible causes for femoroacetabular impingement (FAI). The aim of our study is to describe the radiographic signs of FAl after femoral neck fractures and to compare these data with those of the contralateral hip.

Method: Our institutional medical records database was retrospectively searched for patients $18-50$ years old with a history of femoral neck fractures (OTA 31-B) between 2010-2019. Fifty-two patients were identified. After exclusion criteria, we detected 37 fractures in 37 patients. The mean age of 29 male and 8 female patients was 32,7 (range 18-48) years. The antero-posterior and cross- table lateral views of bilateral hip joints for all 37 patients were reviewed preoperatively and at final follow-up. The mean follow-up period was 48 months (range 6-98 months). In addition, postoperative CT-scans of these patients were also reviewed.

Results: According to OTA classification subtypes, 2 subcapital (31B1), 25 transcervical (31B2) and 10 basicervical (31B3) fractures were detected. The mean alpha angle on lateral X-ray of the operated side was statistically significantly higher than the unaffected side. The mean alpha angle on CT was higher on the operated side than the unaffected side. In addition, the acetabular version angle on CT was higher on the unaffected side while acetabular depth on CT was higher on the operated side. The lateral CE angle on the AP X-ray was not different on the unaffected side compared to the operated side.

Conclusion: Symptoms of impingement can be seen in patients undergoing internal fixation after femoral neck fracture, and a decrease in acetabular version and an increase in acetabular depth may be predisposing to femoral neck fracture.

Keywords: femoroacetabular impingement, femoral neck fracture, CAM type impingement, alpha angle, acetabular version angle

öz

Amaç: Konjenital deformiteler, femur başı epifiz kayması ve Legg-Calve-Perthes hastalığı, femoroasetabular sıkışma (FAl) için olası nedenler olarak öne sürülmüştür. Çalışmamızın amacı femur boyun kırıkları sonrası FAl'nin radyografik bulgularını tanımlamak ve bu verileri karşı kalça ile karşılaştırmaktır. Yöntem: Kurumsal tıbbi kayıt veri tabanımız, 2010-2019 yılları arasında femur boyun kırı̆ı (OTA 31-B) öyküsü olan 18-50 yaş arası hastalar için geriye dönük olarak tarandı. Elli iki hasta belirlendi. Dışlama kriterlerinden sonra 37 hastada kırık tespit ettik. 29 erkek ve 8 kadın hastanın yas ortalaması 32,7 (dağılım 18-48) idi. 37 hastanın tamamı için bilateral kalça eklemlerinin ön-arka ve "cross table" lateral görünümleri ameliyat öncesi ve son takipte gözden geçirildi. Ortalama takip süresi 48 aydı (dağılım 6-98 ay). Ek olarak, bu hastaların postoperatif BT taramaları da gözden geçirildi.

Bulgular: OTA sınıflandırma alt tiplerine göre iki kırık subkapital (31B1), 25'i transservikal (31B2) ve 10'u bazoservikal (31B3) kırıktı. Opere edilen tarafın lateral X-ray'de ortalama alfa açısı istatistiksel olarak etkilenmeyen taraftan anlamlı olarak yüksekti. BT'de ortalama alfa açısı ameliyat edilen tarafta etkilenmeyen tarafa göre anlamlı olarak daha yüksekti. Buna ek olarak, istatistiksel olarak BT'de asetabular derinlik opere edilen tarafta yüksek iken, BT'deki asetabular versiyon açısı etkilenmeyen tarafta daha yüksekti. AP X-ray'de lateral CE açısında etkilenmeyen tarafla opere edilen taraf kıyaslandığında anlamlı fark saptanmadı.

Sonuç: Femur boyun kırığı sonrası internal fiksasyon yapılan hastalarda sıkışma bulguları görülebilmekte ve asetabular versiyonda azalma ve asetabular derinlikte artış femur boyun kırığı için predispozan olabilmektedir.

Anahtar kelimeler: femoroasetabular sıkışma, femur boyun kırığı, CAM tipi sıkışma, alfa açısı, asetabular versiyon açısı

Sorumlu Yazar / Corresponding Author:

Ramadan Özmanevra rozmanevra@gmail.com
A.I. Kilıc 0000-0001-7491-6044 R. Özmanevra 0000-0003-0515-4001 O.N. Eroglu 0000-0002-9807-239X 


\section{INTRODUCTION}

Femoroacetabular impingement (FAI) is recognized as a mechanism for the development of early onset osteoarthritis for most nondysplastic hips. ${ }^{1} \mathrm{FAl}$ is more commonly observed in young and active patients; and without appropriate treatment of chondral and labral lesions it may progress leading to degenerative disease of the hip joint. ${ }^{2}$ Congenital deformities, slipped capital femoral epiphysis and Legg-Calve-Perthes disease have been suggested as possible causes for FAI. ${ }^{3}$ Among with other reasons which deform proximal femoral morphology; an association between malunion after femoral neck fractures and CAM-type FAI have been proposed. ${ }^{4,5}$ Few researchers have addressed the relation of radiological findings of CAM- type FAI, fracture type and grade of arthritis on patients who were treated with internal fixation for femoral neck fractures. ${ }^{6,7}$

However, previous studies focused only on the signs of impingement on the femoral side, and also did not include data from computed tomography (CT) scans and a complete comparison with the contralateral hip was not evaluated. In this study we assessed both femoral and acetabular signs of FAI on X-ray and $\mathrm{CT}$ images of patients who were treated for femoral neck fractures. We also obtained these data for the contralateral unaffected hip joints as a control group, allowing us to compare the signs of FAl with the fractured side, rather than using population- based control groups.

The aim of our study is to describe the radiological signs of FAl after femoral neck fractures and to compare these data with those of the contralateral hip. Our hypothesis was the radiological signs of impingement would be higher on the operated hips than the unaffected sides.

\section{MATERIALS AND METHODS}

After obtaining the local ethical committee approval (Dokuz Eylül University Ethical Committee), our institutional medical records database was retrospectively searched for patients $18-50$ years old with a history of femoral neck fractures (OTA 31-B) between 2010-2019. Fifty-two patients were identified. After exclusion of 2 patients with neurological disorders, 3 patients with pathological fractures, 3 patients with avascular necrosis, 4 patients with non-union and 3 patients who underwent arthroplasty procedures; we detected 37 fractures in 37 patients. Thirty patients were treated with internal fixation using three cannulated screws, and seven patients with dynamic hip screw (DHS) plate fixation. Fracture mechanism, occupation, smoking history and concomitant diseases were assessed.

The mean age of 29 male and 8 female patients was 32.7 (range 18-48) years. The anterolateral and cross- table lateral views of bilateral hip joints for all 37 patients were reviewed preoperatively and at final follow-up. The mean follow-up period was 48 months (range 6-98 months). In addition, postoperative CT-scans of these patients were also reviewed. Radiological assessments of the alpha angle on lateral $\mathrm{X}$-ray, lateral center edge (CE) angle on AP X-ray; and alpha angle, acetabular depth and acetabular version on CT views were performed .

Alpha angle was measured according to the method described by Nötzli et al. ${ }^{8}$

In this method, a line is drawn along the longitudinal axis of the femoral neck at the narrowest point between the center of the femoral head and the center of the femoral neck. Next, the frontal size of the concavity of the femoral neck is determined using a circular template. A point is marked, in which the radius of curvature of the femoral head first deviates from the circular pattern. From this point, a straight line is connected to the center of the femoral head. The angle measured between the longitudinal axis of the femoral neck and this line represents the alpha angle (Figure 1). All measurements were performed

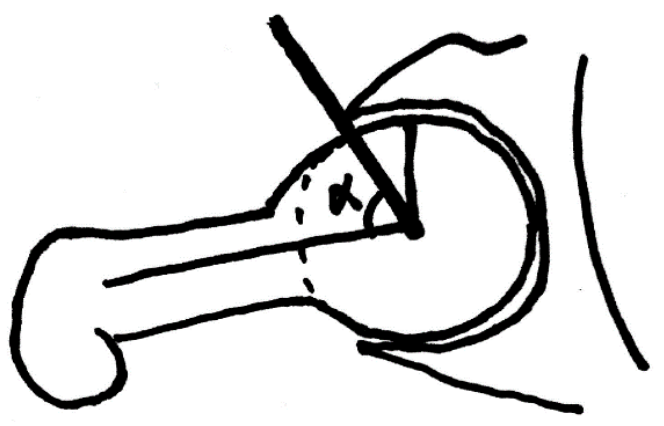

Fig.1: The measurement of alpha angle. The angle measured between the longitudinal axis of the femoral neck and the bold line. 
by two orthopedic surgeons.

The lateral CE angle was measured as previously described between a line perpendicular to the lower teardrop line and another line between the center of the femoral head and the lateral acetabular roof edge. ${ }^{9}$

CT examinations were performed by positioning the femurs in neutral rotation, hips and knees extended, and patella directly facing up while the patient was lying in the supine position. The scanograms of lower extremities including the anterior superior iliac spine were obtained on the frontal plane.

Patients were scanned according to standard departmental protocols at $120 \mathrm{kVp}$ and 140 to 180 mAs depending on patient weight and/or girth. Axial CT images with $3 \mathrm{~mm}$ slice thickness were obtained according to standard local protocols.

When measuring acetabular anteversion, a coronal slice (slice B) was selected, which ensures optimal

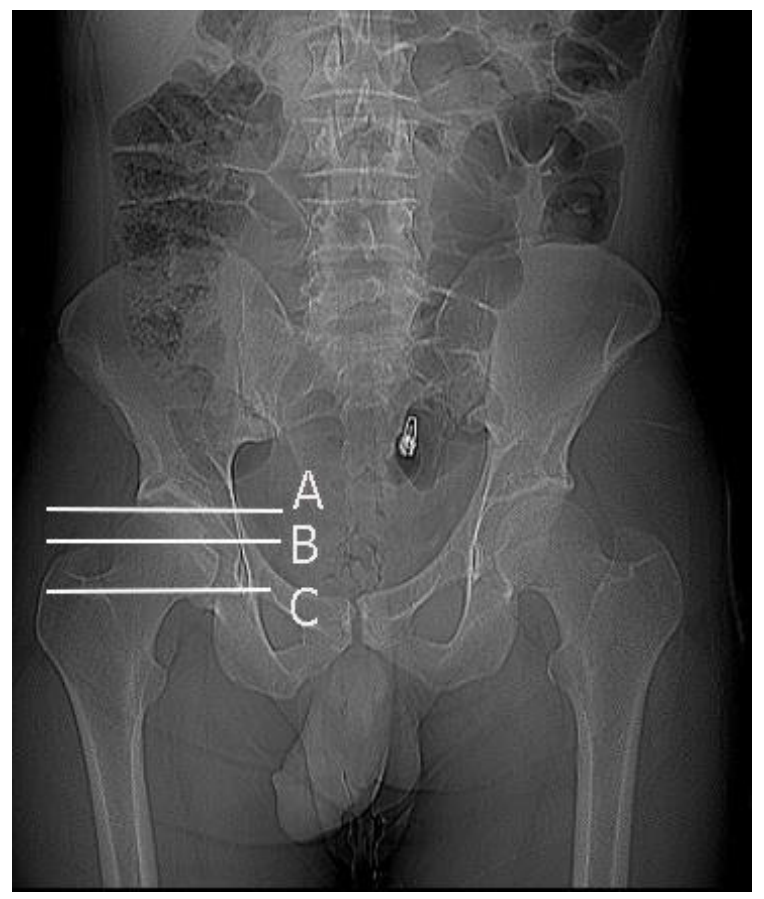

Fig 2: While measuring acetabular anteversion, a coronal slice (slice B) was selected, which ensures optimal visualization of the pelvic teardrop.

visualization of the pelvic teardrop (Figure 2). The slope resulting from the patient's incorrect positioning in the CT scanner was checked by drawing a baseline that intersects the posterior edges of the

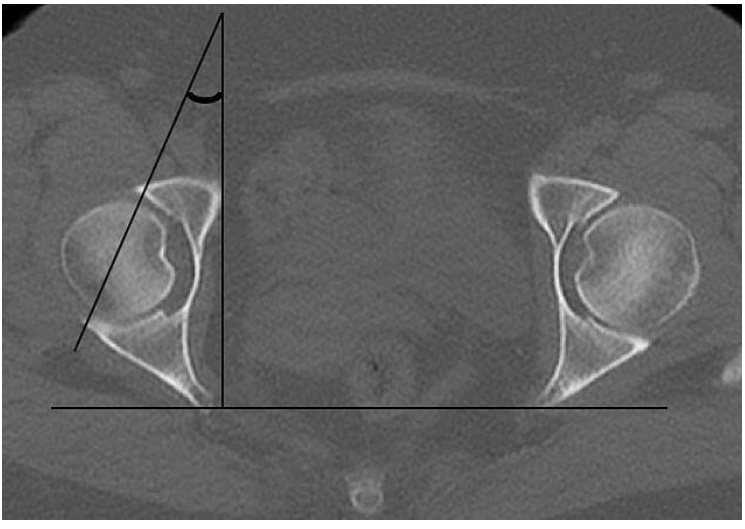

Fig.3: The acetabular version was measured in the axial section corresponding to the slice B in the coronal plane as an angulation between the anterior lip and posterior lip of the acetabulum.

ilium (Figure 2). The acetabular anteversion was then measured in the axial section corresponding to the slice $B$ in the coronal plane (Figure 3 ). Acetabular anteversion is the angulation of the sagittal plane relative to the line between the anterior and posterior lips of the acetabulum. ${ }^{10}$

Statistical analyses were performed with SPSS software 25.0 (SPSS, Chicago, IL, USA). The fitness of the data to the normal distribution was performed using the Shapiro-Wilk test and the measurements of the unaffected side. Since the operated side measurement data were compared with the unaffected side data of the same person, paired tests were used to compare dependent groups. Normally distributed data were analyzed with paired sample t- test and non-normally distributed data with nonparametric Wilcoxon Signed-Rank test. Statistical test result was considered statistically significant at the $p$-value $<0.05$ level.

\section{RESULTS}

According to OTA classification of fracture subtypes, 2 subcapital (31B1) , 25 transcervical (31B2) and 10 basicervical (31B3) fractures were detected. According to Garden classification, seven type 1, seven type 2, 20 type 3 and four type 4 fractures were detected. ${ }^{11}$

The mean alpha angle on lateral X-ray was $44.4^{\circ} \pm 7.35^{\circ}$ on the unaffected, and $54 .{ }^{\circ} 2 \pm 8.37^{\circ}$ on the operated side. The alpha angle of the operated side was statistically higher than the unaffected side $(p<0.001)$. There was no statistically significant 
difference between unaffected and operated side regarding lateral CE angle on AP X-ray.

The mean alpha angle on CT was statistically significantly higher on the operated side than the unaffected side $(p<0.001)$. In addition, the acetabular version angle on $\mathrm{CT}$ was higher on the unaffected side while acetabular depth on CT was higher on operated side $(p<0.01)($ Table-1).

Table 1. The measurements performed on X-ray and CT.

\begin{tabular}{|c|c|c|c|c|c|}
\hline & $\begin{array}{l}\text { Unaffected } \\
\text { Side } \\
(n=37)\end{array}$ & $\begin{array}{l}\text { Operated } \\
\text { Side } \\
(n=37)\end{array}$ & \multicolumn{3}{|c|}{$\begin{array}{l}\text { Paired sample t- test }{ }^{\mathrm{a}} \text { / } \\
\text { Wilcoxon Signed- } \\
\text { Rank Test }^{\mathrm{b}}\end{array}$} \\
\hline & Mean $\pm S D$ & $\begin{array}{l}\text { Mean } \\
\pm S D\end{array}$ & $\begin{array}{l}\text { Mean } \\
\text { differ- } \\
\text { ence }\end{array}$ & $t / Z$ & $\begin{array}{l}\mathrm{p} \\
\text { value }\end{array}$ \\
\hline $\begin{array}{l}\text { Alpha } \\
\text { angle on } \\
\text { lateral } \\
\text { X-ray }\end{array}$ & $\begin{array}{l}44.4 \pm \\
7.35\end{array}$ & $\begin{array}{l}54.2 \pm \\
8.37\end{array}$ & -9.82 & 5.27 & $\begin{array}{l}<0.001 \\
b\end{array}$ \\
\hline $\begin{array}{l}\text { Lateral CE } \\
\text { angle on } \\
\text { AP X-ray }\end{array}$ & $\begin{array}{l}35.6 \pm \\
9.76\end{array}$ & $\begin{array}{l}35.6 \pm \\
6.54\end{array}$ & 0.01 & 0.01 & $0.996^{a}$ \\
\hline $\begin{array}{l}\text { Alpha } \\
\text { angle on } \\
\text { CT }\end{array}$ & $\begin{array}{l}44.6 \pm \\
7.09\end{array}$ & $\begin{array}{l}54.7 \pm \\
7.61\end{array}$ & -10.18 & 5.29 & $\begin{array}{l}<0.001 \\
b\end{array}$ \\
\hline $\begin{array}{l}\text { Acetabular } \\
\text { version } \\
\text { angle on } \\
\text { CT }\end{array}$ & $\begin{array}{l}18.8 \pm \\
4.84\end{array}$ & $\begin{array}{l}16.6 \pm \\
6.35\end{array}$ & -9.82 & 2.53 & $<0.01^{b}$ \\
\hline $\begin{array}{l}\text { Acetabular } \\
\text { depth } \\
(\mathrm{mm}) \text { on } \\
\text { CT }\end{array}$ & $\begin{array}{l}23.4 \pm \\
3.55\end{array}$ & $\begin{array}{l}25.2 \pm \\
3.70\end{array}$ & -1.82 & 2.70 & $<0.01^{a}$ \\
\hline
\end{tabular}

\section{DISCUSSION}

The most important finding of our study was the significant difference between the alpha angles of operated and unaffected sides. The mean alpha angle on $\mathrm{CT}$ was higher on the operated side than the unaffected side. In addition, the acetabular version angle on $\mathrm{CT}$ was significantly higher on the unaffected side.

In a study, Mathew et al. ${ }^{6}$ reviewed a total of 187 radiographs to evaluate and estimate the radiographic prevalence of CAM-type impingement who underwent internal fixation for femoral neck fracture. For this purpose, they evaluated alpha angle, beta angle and anterior head-neck offset. They detected an $85 \%$ prevalence of radiologically detected CAM-type FAl following internal fixation of femoral neck fractures and the mean alpha angle was $67^{\circ}$; whereas in our study the mean alpha angle was $54.2^{\circ}$. Gosvig et al. ${ }^{12}$ assessed the prevalence of CAM deformity in 3202 standardized AP pelvic radiographs. They found gender -related differences in the distribution of CAM deformity ( $17 \%$ in men and $4 \%$ in women). In our study, since the number of female and male patients was not comparable, we did not investigate gender-related differences regarding the distribution of CAM deformities. The prevalence of CAM deformities in Mathew et al's study was higher than that found by Gosvig et al that reported prevalence rates in young population without fractures. Similarly, other studies investigating the prevalence of FAI have reported lower rates. ${ }^{13,14}$

Malreduction of the femoral neck after fracture has been showed as a cause for developing FAl by several studies. ${ }^{4,5,14}$ In their study, Wendt et al. ${ }^{7}$ aimed to determine the prevalence of radiologically detected impingement in OTA type 31B after treatment with internal fixation. They used alpha angle, femoral head retroversion and Mose templates as measurements to determine impingement. Their series showed a $46 \%$ prevalence of abnormal alpha angle in 31B fractures, even this rate was as high as $63 \%$ in one subgroup (type 31B3). In our study instead of femoral head version, acetabular version was examined. A significant difference between the operated and the intact sides in terms of acetabular version was observed. The mean acetabular version angle was significantly lower on the operated side.

Disorders related to acetabular orientation have been associated with the etiology of different hip pathologies. Diseases such as hip osteoarthritis, hip dysplasia, Legg-Calve-Perthes have been shown among these various hip pathologies. ${ }^{15-17}$ Acetabular retroversion can also biomechanically affect the proximal femur.

In a retrospective study conducted on 54 patients, Kuhn et al. ${ }^{18}$ concluded that the incidence of 
acetabular retroversion was higher in cases of femoral neck stress fractures developing in military soldiers. Similarly, in the study of Goldin et al. ${ }^{19}$ patients with femoral neck stress fractures were evaluated in terms of radiographic findings of FAl. The authors stated that the results obtained from the study suggested that patients with femoral neck stress fractures had more common Pincer type impingement findings than the normal population. Contrary to these studies, Frost et al. ${ }^{20}$ emphasized that although they thought that acetabular retroversion may be a risk factor for intracapsular hip fractures, they did not find any correlation between the fracture type and acetabular version in their study. In our study, we found a significant difference in the acetabular version between the unaffected contralateral hip and the hip which underwent open reduction and internal fixation due to a femoral neck fracture which may suggest that acetabular retroversion increases the risk of femoral neck fractures.

The findings of our study support the idea that CAMtype impingement may develop due to increased alpha angle after femoral neck fractures. Acetabular retroversion, which is another finding of femoroacetabular impingement, was also evaluated in this study and found to be higher on the operated side. In addition, X-ray as well as CT images were examined in our study. This was one of the strengths of our study. The other strength in this study was the selection of the contralateral unaffected hips of patients as control group.

This study also had several limitations. The small number of patients and being performed retrospectively were two main limitations of our study. Finally, we could not definitely report that decreased acetabular anteversion with possible CAM deformity and/or decreased hip range of motion would increase the risk of femoral neck fractures due to absence of radiographs or physical examination findings before the fracture developed.

\section{CONCLUSION}

Impingement findings can be seen not only on the femoral side but also on the acetabular side in patients undergoing internal fixation after femoral neck fractures. It should be kept in mind that acetabular retroversion with possible CAM deformity may also be associated with the risk of femoral neck fracture, and perhaps it should be investigated by prospective studies.

Ethics Committee Approval: 2020/10-21 (Dokuz Eylül University Ethics Committee)

Conflict of Interest: None

Funding: None

Informed Consent: Consent was not obtained because of the retrospective nature of the study.

\section{REFERENCES}

1. Ganz R, Parvizi J, Beck M, et al. Femoroacetabular impingement: a cause for osteoarthritis of the hip. Clin Orthop Relat Res. 2003;417:112-20.

2. Klaue K, Durnin CW, Ganz R. The acetabular rim syndrome: a clinical presentation of dysplasia of the hip. J Bone Joint Surg [Br]. 1991;73-B:423-9. https://doi.org/10.1302/0301-620X.73B3.1670443

3. Allen D, Beaule PE, Ramadan O, Doucette S. Prevalence of associated deformities and hip pain in patients with CAM-type femoroacetabular impingement. J Bone Joint Surg Br. 2009;91(5):589-94. https://doi.org/10.1302/0301-620X.91B5.22028

4. Ganz R, Bamert P, Hausner $P$, et al. Cervicoacetabular impingement after femoral neck fracture. Unfallchirurg. 1991;94(4):172-5.

5. Eijer H, Myers SR, Ganz R. Anterior femoroacetabular impingement after femoral neck fractures. J Orthop Trauma. 2001;15(7):475-81 https://doi.org/10.1097/00005131-200109000-00003

6. Mathew G, Kowalczuk M, Hetaimish B, et al; FAITH Investigators. Radiographic prevalence of CAMtype femoroacetabular impingement after open reduction and internal fixation of femoral neck fractures. Knee Surg Sports Traumatol Arthrosc. 2014 Apr;22(4):793-800. https://doi.org/10.1007/s00167-014-2835-6

7. Wendt MC, Cass JR, Trousdale RR. Incidence of radiographic CAM-type impingement in young patients $(<50)$ after femoral neck fracture treated with reduction and internal fixation. HSS J. 2013 Jul;9(2):113-7. https://doi.org/10.1007/s11420-012-9325-5

8. Nötzli HP, Wyss TF, Stoecklin $\mathrm{CH}$, et al. The contour of the femoral head-neck junction as a predictor for the risk of anterior impingement. J Bone Joint Surg Br. 2002;84(4):556-60. https://doi.org/10.1302/0301-620X.84B4.0840556

9. Wiberg $\mathrm{G}$. The anatomy and roentgenographic appearance of a normal hip joint. Acta Chir Scand. 1939;83 Suppl 58: 7-38.

10. Dandachli W, UI Islam S, Tippett R, Hall-Craggs MA, Witt JD. Analysis of acetabular version in the native hip: comparison between 2D axial CT and 3D CT measurements. Skeletal Radiol. 2011;40(7):877-83. https://doi.org/10.1007/s00256-010-1065-3

11. Garden RS. Low-angle fixation in fractures of the femoral neck. J Bone Joint Surg Br. 1961;43:647-663. https://doi.org/10.1302/0301-620X.43B4.647 
12. Gosvig KK, Jacobsen S, Sonne-Holm S, Gebuhr P. The prevalence of CAM-type deformity of the hip joint: a survey of 4151 subjects of the Copenhagen Osteoarthritis Study. Acta Radiol. 2008;49(4):436-41.

https://doi.org/10.1080/02841850801935567

13. Hack K, Di Primio G, Rakhra K, Beaule PE. Prevalence of CAMtype femoroacetabular impingement morphology in asymptomatic volunteers. J Bone Joint Surg Am. 2010;92(14):2436-44.

https://doi.org/10.2106/JBJS.J.01280

14. Takeyama A, Naito M, Shiramizu K, Kiyama T. Prevalence of femoroacetabular impingement in Asian patients with osteoarthritis of the hip. Int Orthop. 2009;33(5):1229-32. https://doi.org/10.1007/s00264-009-0742-0

15. Ezoe $M$, Naito $M$, Inoue $T$. The incidence of acetabular retroversion among various disorders of the hip. J Bone Joint Surg Am. 2006;88:372-379.

https://doi.org/10.2106/00004623-200602000-00017

16. Kim WY, Hutchinson CE, Andrew JG, Allen PD. The relationship between acetabular retroversion and osteoarthritis of the hip. J Bone Joint Surg Br. 2006;88:727-729.

https://doi.org/10.1302/0301-620X.88B6.17430

17. Li PL, Ganz R. Morphologic features of congenital acetabular dysplasia: one in six is retroverted. Clin Orthop Relat Res. 2003;(416):245-253.

https://doi.org/10.1097/01.blo.0000081934.75404.36

18. Kuhn KM, Riccio Al, Saldua NS, Cassidy J. Acetabular retroversion in military recruits with femoral neck stress fractures. Clin Orthop Relat Res. 2010 Mar;468(3):846-51. https://doi.org/10.1007/s11999-009-0969-5

19. Goldin M, Anderson CN, Fredericson M, Safran MR, Stevens KJ. Femoral Neck Stress Fractures and Imaging Features of Femoroacetabular Impingement. PMR. 2015 Jun;7(6):584-92. https://doi.org/10.1016/j.pmrj.2014.12.008

20. Frost A, Pavlou G, Richards PJ, Belcher J, Jasani V. Influence of Acetabular and Femoral Version on Fractures of the Femoral Neck. Clin Orthop Relat Res. 2010 Aug; 468(8): 2224-2229. https://doi.org/10.1007/s11999-009-1185-z 